\title{
Association of RBP4 Genotype with Phenotypic Reproductive Traits of Sows
}

\author{
A. Marantidis, G. P. Laliotis, and M. Avdi \\ Laboratory of Physiology of Reproduction of Farm Animals, Department of Animal Production, School of Agriculture, \\ Aristotle University of Thessaloniki, 54124 Thessaloniki, Greece
}

Correspondence should be addressed to G. P. Laliotis; georgelaliotis@hotmail.com

Received 22 September 2015; Accepted 24 December 2015

Academic Editor: Norman A. Doggett

Copyright (C) 2016 A. Marantidis et al. This is an open access article distributed under the Creative Commons Attribution License, which permits unrestricted use, distribution, and reproduction in any medium, provided the original work is properly cited.

PCR-RFLP was applied to a commercial crossbred pig population in order to investigate the association between polymorphism (SNP) of Retinol-binding protein 4 (RBP4) gene and reproductive performance. 400 sows were genotyped and 2000 records of reproductive traits were used in order to retrieve information about the allele frequencies and the association of the RBP4 gene with main reproductive characteristics of the population. A deviation from the Hardy-Weinberg equilibrium was observed as a result of the AB genotype excess. In addition, the AA genotype saw statistically significant higher values of (i) the total number of born piglets $(p<0.05)$, (ii) the number of piglets born alive $(p<0.01)$, and (iii) the number of weaned piglets $(p<0.01)$. The number of the mummified piglets and the number of the piglets born dead did not differ between the various RBP4 genotypes. Interestingly, the AA genotype had a negative impact $(p<0.05)$ on the number of piglets born dead, resulting indirectly in a larger litter size. In conclusion, the AA genotype and in extension the A allele of RBP4 gene are in favor of producing larger litter size, suggesting that the RBP4 gene may be used in Marker-Assisted Selection (MAS) programs for a rapid improvement of the reproductive characteristics in pigs.

\section{Introduction}

The implementation of reliable genetic markers on the Marker-Assisted Selection (MAS) programs applied to the pig industry may result in small to moderate increases in litter size that would improve farm economic performance. In addition, the early selection of the sows, before they reach reproductive maturity, would stop breeding low-performance sows [1]. An effective way to detect genetic markers is the candidate gene approach, where the identification of gene polymorphisms that cause variation in a trait is based on physiological, immunological, or endocrine evidence [2].

The RBP4 gene is expressed during the period of fast elongation of the pig blastocyst [3]. This is a critical period for the survival of the embryos. Harney et al. [4] reported an increased expression of the RBP4 gene in the gravid endometrium, between the 10th to 12th day of pregnancy of sows, suggesting that the respective coding protein (RBP4) plays an important role in uterine and conceptus physiology during the establishment of pregnancy. In addition, Retinolbinding protein 4 (RBP4) has been found to be a major secretory product of the pig conceptus prior to implantation [5]. Therefore, RBP4 is reported as a candidate gene for litter size owing to its possible role at the time of embryonic development [1].

An initial study in hyperprolific and control sows yielded an estimated additive effect (0.4 piglets/birth) of RBP4 gene [6]. In a follow-up study, Rothschild et al. [1] checked whether this effect was also detectable in commercial lines of pigs. They found an approximate additive effect of 0.23 pigs per litter $(p<0.05)$ for TNB (total number of born piglets) and 0.15 pigs per litter for NBA (number of piglets born alive) suggesting that RBP4 probably affects the litter size in some commercial lines. However, later studies in various crossbreds and pure breeds have not always confirmed these results. Even though the same trend was obtained in most cases, a statistically significant difference was not always observed $[7,8]$ or it was restricted to some parities $[9,10]$. 
One of the major problems of the Greek pig industry is the low prolificacy performance reflecting a narrow economic income. To the best of our knowledge there is no previous reported study investigating any interaction between RBP4 gene polymorphism and reproductive traits in Greek pig farming, as a tool of identification of the more productive animals. Therefore, the aim of this study was to determine any possible associations of the RBP4 genotypes with main reproductive traits of sows in a commercial population reared in Greece, so as to enable such information to be used in the future for breeding selection schemes.

\section{Materials and Methods}

2.1. Animals and Data Collection. The pig population was derived from a Greek commercial farm (North Western of Greece). 400 sows in total (crossbreed from Large White $\times$ Landrace) were genotyped. The sows were randomly selected from the whole population of farm among those who gave their first birth at the age of 12 months and had at least 5 continuous litters. Sows were artificially inseminated with fresh semen derived from Duroc $\times$ Pietrain boars. All sows were kept under the same feeding and housing conditions and their reproductive performance was permanently recorded by the staff of the farm. Reproductive traits that were taken into account were (i) the total number of born piglets (TNB), (ii) the number of piglets born alive (NBA), (iii) the number of piglets born dead (NBD), (iv) the number of mummified piglets (NBM), (v) the number of aborted piglets (ABRT), and (vi) the number of weaned piglets (NW).

2.2. DNA Isolation and Genotyping. Polymerase chain reaction-restriction fragment length polymorphism (PCRRFLP) for the RBP4 gene genotyping was performed. DNA was extracted from hair roots or blood of the sows, using the Nucleospin blood or tissue kits (Macherey-Nagel, Germany). An electrophoresis was performed to ensure the integrity of the DNA samples. Concerning the PCR procedure, the primer sequences used were $5^{\prime}$-GAGCAAGATGGAATGGGTT-3' and $5^{\prime}$-CTCGGTGTCTGTAAAGGTG-3' for the forward and the reverse primer, respectively [1]. The PCR amplification was performed as follows: approximately $150 \mathrm{ng}$ of genomic DNA was used as template and amplified in a final volume of $25 \mu \mathrm{L}$ containing $200 \mathrm{nM}$ of each primer, $1 \mathrm{mM}$ dNTPs, and 1 unit MyTaq DNA Polymerase (Bioline). PCR amplification was performed using the following conditions: initial denaturation at $95^{\circ} \mathrm{C}$ for $5 \mathrm{~min}, 30$ amplification cycles including denaturation at $95^{\circ} \mathrm{C}$ for $30 \mathrm{~s}$, annealing at $56^{\circ} \mathrm{C}$ for $30 \mathrm{~s}$, and extension at $72^{\circ} \mathrm{C}$ for $45 \mathrm{~s}$ and a final extension step at $72^{\circ} \mathrm{C}$ for $10 \mathrm{~min}$. Finally, $15 \mu \mathrm{L}$ of PCR product ( $550 \mathrm{bp}$ ) was digested in a total volume of $20 \mu \mathrm{L}$, containing $10 \mathrm{U}$ of enzyme MspI (Takara), $2 \mu \mathrm{L}$ of restriction buffer, and $2 \mu \mathrm{L}$ of BSA for 3 hours. Restriction fragments were examined by electrophoresis on $2.5 \%$ agarose gel with $1 \mathrm{x}$ TBE buffer.

2.3. Statistical Analysis. Genotype frequencies, allele frequencies, and Hardy-Weinberg equilibrium estimations were calculated using PopGene Software v. 1.32 [11]. The statistical
TABLE 1: Genotype distribution and allele frequencies of the RBP4 gene in the analyzed population.

\begin{tabular}{lccc}
\hline Genotype & Observed & Expected & Frequencies $(P)$ \\
\hline AA & 113 & 125 & 0.28 \\
AB & 221 & 197 & 0.55 \\
BB & 66 & 78 & 0.17 \\
\hline
\end{tabular}

$p=0.56 ; q=0.44 ; \chi^{2}=5.81 ; \mathrm{df}=1$.

procedures were performed using the SPSS program (version 19.0). A mixed statistical model was used for the analysis of associations between the RBP4 genotypes and the total number of born piglets (TNB), the number of piglets born alive (NBA), the number of piglets born dead (NBD), the number of piglets born mummified (BMUM), the number of aborted piglets (ABRT), and the number of weaned piglets (NW). Due to the uneven distribution of the first litters, their parameters were analyzed separately. The statistical models used in the analysis were as follows:

$$
Y_{i j k}=\mu+G_{i}+L_{j}+\left(G_{i} * L_{j}\right)+T_{k}+e_{i j k},
$$

where $Y_{i j k}$ is trait value, $\mu$ is the general mean, $G_{i}$ is the fixed effect of RBP4 genotype ( $i=1,2,3), L_{j}$ is the fixed effect of the litter parity $(j=2,3,4,5), G_{i} * L_{j}$ is the effect of the interaction between the $i$ genotype and the $j$ litter parity, $T_{k}$ is the random effect of the sow $(k=1,2, \ldots, 400)$, and $e_{i j k}$ is the random error.

When the data of the examined traits were analyzed for each parity separately, the factors regarding $L_{j}$ (the fixed effect of litter parity) and $G_{i} * L_{j}$ (the effect of interaction between the $i$ genotype and the $j$ litter parity) were excluded from the model.

\section{Results}

3.1. Genotype and Allele Distribution of RBP4 Gene. Two RBP4 alleles (A, B) and three genotypes, namely, AA, AB, and $\mathrm{BB}$, were identified in the examined population. The allelic and genotypic frequencies are presented in Table 1. Allele frequencies were 0.56 and 0.44 for allele A and allele B, respectively. A heterozygosity excess was observed, while the population was found to deviate $(p<0.05)$ from the HardyWeinberg equilibrium.

3.2. Association of Sows' Reproductive Traits and RBP4 Genotypes. The results of mean TNB, NBA, NBD, NBM, ABRT, and NW values (piglets/birth) in regard to the observed RBP4 genotypes are presented in Table 2 . Statistically significant differences were detected between genotypes $\mathrm{AA}$ and $\mathrm{AB}$ as well as between $\mathrm{AA}$ and $\mathrm{BB}$ genotypes for almost all analyzed reproductive traits. Specifically, in regard to the TNB value, the AA genotype showed a higher $(p<0.05)$ number of piglets/litter $(13.82 \pm 0.10)$ compared to the $\mathrm{AB}$ $(13.51 \pm 0.07)$ and the $\mathrm{BB}(13.44 \pm 0.13)$ genotype. The same significant $(p<0.01)$ trend was also observed for the number of born piglets (NBA) in reference to the respective RBP4 genotypes. Nonsignificant differences were observed 
TABLE 2: Association of major reproductive traits with RBP4 genotypes among four parities $(N=400,2-5$ parities $)$. The values presented as mean $\pm \mathrm{SEM}^{\dagger}$.

\begin{tabular}{lcccccc}
\hline Genotype & TNB & NBA & NBD & NBM & ABRT & NW \\
\hline AA & $13.82 \pm 0.10^{\mathrm{a}, *}$ & $13.02 \pm 0.11^{\mathrm{a}, * *}$ & $0.54 \pm 0.04^{\mathrm{a}, *}$ & $0.25 \pm 0.03^{\mathrm{NS}}$ & $0.04 \pm 0.10^{\mathrm{NS}}$ & $12.30 \pm 0.11^{\mathrm{a}, * *}$ \\
AB & $13.51 \pm 0.07^{\mathrm{b}, *}$ & $12.61 \pm 0.08^{\mathrm{b}, * *}$ & $0.64 \pm 0.03^{\mathrm{b}, *}$ & $0.27 \pm 0.02^{\mathrm{NS}}$ & $0.05 \pm 0.07^{\mathrm{NS}}$ & $11.91 \pm 0.08^{\mathrm{b}, * *}$ \\
BB & $13.44 \pm 0.13^{\mathrm{b}, *}$ & $12.55 \pm 0.14^{\mathrm{b}, * *}$ & $0.60 \pm 0.05^{\mathrm{b}, *}$ & $0.29 \pm 0.04^{\mathrm{NS}}$ & $0.03 \pm 0.01^{\mathrm{NS}}$ & $11.78 \pm 0.14^{\mathrm{b}, * *}$ \\
\hline
\end{tabular}

${ }^{\dagger}$ TNB: total number of born piglets; NBA: number of piglets born alive; NBD: number of piglets born dead; NBM: number of mummified piglets; ABRT: number of aborted piglets; NW: number of weaned piglets. ${ }^{\mathrm{a} b}$ Different superscripts in the same column indicate significant difference $\left({ }^{*} p<0.05 ;{ }^{* *} p<0.01\right.$; ${ }^{\mathrm{NS}}$ not significant).

TABLE 3: Genotype performance among the parities of 400 sows.

\begin{tabular}{|c|c|c|c|c|c|c|c|c|}
\hline Parity & Genotype & $n$ & $\begin{array}{c}\text { TNB } \\
(\text { mean }+ \text { SD })\end{array}$ & $\begin{array}{c}\text { NBA } \\
(\text { mean }+ \text { SD })\end{array}$ & $\begin{array}{c}\text { NBD } \\
(\text { mean + SD })\end{array}$ & $\begin{array}{c}\mathrm{NBM} \\
(\text { mean }+\mathrm{SD})\end{array}$ & $\begin{array}{c}\text { ABRT } \\
(\text { mean }+ \text { SD })\end{array}$ & $\begin{array}{c}\mathrm{NW} \\
(\text { mean }+\mathrm{SD})\end{array}$ \\
\hline \multirow{3}{*}{1 st } & AA & 113 & $11.73 \pm 2.13$ & $10.90 \pm 2.18$ & $0.56 \pm 0.72$ & $0.27 \pm 0.67$ & $0.04 \pm 0.18$ & $10.47 \pm 2.15^{\mathrm{a}, * *}$ \\
\hline & $\mathrm{AB}$ & 221 & $11.52 \pm 1.98$ & $10.59 \pm 2.10$ & $0.66 \pm 0.78$ & $0.28 \pm 0.62$ & $0.05 \pm 0.23$ & $10.03 \pm 2.05^{\mathrm{b}}$ \\
\hline & $\mathrm{BB}$ & 66 & $11.56 \pm 2.21$ & $10.48 \pm 2.50$ & $0.65 \pm 1.30$ & $0.42 \pm 1.42$ & $0.03 \pm 0.17$ & $10.15 \pm 2.66^{\mathrm{b}}$ \\
\hline \multirow{3}{*}{ 2nd } & AA & 113 & $13.25 \pm 2.00$ & $12.58 \pm 2.14$ & $0.44 \pm 0.61$ & $0.22 \pm 0.56$ & $0.04 \pm 0.18$ & $11.85 \pm 2.19^{\mathrm{a}, *}$ \\
\hline & $\mathrm{AB}$ & 221 & $12.96 \pm 2.04^{\mathrm{a}, * *}$ & $12.15 \pm 2.34^{\mathrm{a}, * *}$ & $0.53 \pm 0.70$ & $0.27 \pm 0.78$ & $0.05 \pm 0.23$ & $11.39 \pm 2.419^{\mathrm{b}, *}$ \\
\hline & $\mathrm{BB}$ & 66 & $12.71 \pm 2.38^{\mathrm{b}, * *}$ & $11.97 \pm 2.46^{\mathrm{b}, * *}$ & $0.53 \pm 0.98$ & $0.21 \pm 0.45$ & $0.03 \pm 0.17$ & $11.29 \pm 2.58^{\mathrm{a}, * *}$ \\
\hline \multirow{3}{*}{$3 \mathrm{rd}$} & AA & 113 & $14.04 \pm 2.15^{\mathrm{a}, *}$ & $13.11 \pm 2.22^{\mathrm{a}, *}$ & $0.69 \pm 0.73$ & $0.24 \pm 0.51$ & $0.04 \pm 0.18$ & $12.31 \pm 2.29^{\mathrm{a}, *}$ \\
\hline & $\mathrm{AB}$ & 221 & $13.51 \pm 2.17^{\mathrm{b}, *}$ & $12.56 \pm 2.26^{\mathrm{b}, *}$ & $0.69 \pm 0.83$ & $0.26 \pm 0.52$ & $0.05 \pm 0.23$ & $11.78 \pm 2.29^{\mathrm{b}, *}$ \\
\hline & $\mathrm{BB}$ & 66 & $13.53 \pm 2.32^{\mathrm{a}, *}$ & $12.58 \pm 2.42^{\mathrm{a}, *}$ & $0.55 \pm 0.86$ & $0.41 \pm 0.66$ & $0.03 \pm 0.17$ & $11.67 \pm 2.46^{\mathrm{a}, *}$ \\
\hline \multirow{3}{*}{ 4th } & $\mathrm{AA}$ & 113 & $14.12 \pm 2.39$ & $13.30 \pm 2.59^{\mathrm{a}, *}$ & $0.54 \pm 0.67$ & $0.27 \pm 0.52$ & $0.04 \pm 0.19$ & $12.34 \pm 2.55^{\mathrm{a}, *}$ \\
\hline & $\mathrm{AB}$ & 221 & $13.8 \pm 2.31$ & $12.80 \pm 2.40^{\mathrm{b}, *}$ & $0.72 \pm 0.79$ & $0.28 \pm 0.53$ & $0.05 \pm 0.23$ & $11.98 \pm 2.44^{\mathrm{b}, *}$ \\
\hline & $\mathrm{BB}$ & 66 & $13.98 \pm 2.50$ & $13.11 \pm 2.61^{\mathrm{a}, *}$ & $0.62 \pm 0.67$ & $0.26 \pm 0.62$ & $0.03 \pm 0.17$ & $11.97 \pm 2.74^{\mathrm{a}, *}$ \\
\hline \multirow{3}{*}{5 th } & $\mathrm{AA}$ & 113 & $13.87 \pm 2.16^{\mathrm{a}, *}$ & $13.08 \pm 2.09^{\mathrm{a}, *}$ & $0.50 \pm 0.63$ & $0.29 \pm 0.66$ & $0.04 \pm 0.19$ & $12.71 \pm 1.95^{\mathrm{a}, *}$ \\
\hline & $\mathrm{AB}$ & 221 & $13.76 \pm 1.95^{\mathrm{b}, *}$ & $12.93 \pm 1.76^{\mathrm{b}, *}$ & $0.60 \pm 0.67$ & $0.28 \pm 0.52$ & $0.05 \pm 0.23$ & $12.51 \pm 1.73^{\mathrm{b}, *}$ \\
\hline & $\mathrm{BB}$ & 66 & $13.52 \pm 2.15$ & $12.54 \pm 2.12^{\mathrm{a}, *}$ & $0.71 \pm 0.82$ & $0.28 \pm 0.55$ & $0.03 \pm .0 .17$ & $12.18 \pm 1.97^{\mathrm{a}, *}$ \\
\hline
\end{tabular}

${ }^{\dagger}$ TNB: total number of born piglets; NBA: number of piglets born alive; NBD: number of piglets born dead; NBM: number of mummified piglets; ABRT: number of aborted piglets; NW: number of weaned piglets. ${ }^{a, b}$ Different superscripts in the same column and parity indicate significant difference $\left({ }^{*} p<0.05\right.$; $\left.{ }^{* *} p<0.01\right)$.

for the number of piglets born mummified (BMUM) and the aborted piglets (ABRT) among the observed RBP4 genotypes. Interestingly, the AA genotype gave a statistically significant $(p<0.05)$ lower number of piglets born dead (NBD) per litter $(0.54 \pm 0.04)$ with respect to the two other analyzed genotypes. Moreover, the sows with the AA genotype had also larger number $(p<0.01)$ of piglets than the sows carrying the $\mathrm{AB}$ and the $\mathrm{BB}$ genotypes. Specifically, the $\mathrm{AA}$ genotype produced 0.52 weaned piglets $(\mathrm{NW})$ more than the $\mathrm{BB}$ genotypic sows. This difference also remained statistically significant $(p<0.01)$ in the first parity (Table 3$)$, with the AA genotype still having the largest litter size $(10.47 \pm 2.15)$ compared to the $\mathrm{AB}(10.03 \pm 2.05)$ and the $\mathrm{BB}(10.15 \pm$ 2.66) genotype. As far as it concerns TNB and NBA traits, it revealed that the $\mathrm{AA}$ and/or the $\mathrm{AB}$ genotypes are in favor of producing larger litter size in regard to the BB genotype among all analyzed parities (Table 3), except the first parity.

\section{Discussion}

Herein we reported the influence of the RBP4 gene on the prolificacy of a crossbreed population reared in Greece.
400 sows were genotyped and 2000 records were used in order to retrieve information about allele frequencies and the association of the RBP4 gene on main reproductive characteristics of the population.

According to our data, an excess of the $\mathrm{AB}$ genotype was observed and a higher frequency of allele $A(0.56)$ with respect to allele B was noted. Similar allelic frequencies have been reported for Large White and Landrace $\times$ Large White populations $[1,7,12-14]$ and in Black Slavonian sows [15]. Higher allelic values for A allele have been previously reported in Duroc [16] and in Polish Landrace [17] sows populations, while lower values have been reported by Kapelański et al. [18] in Polish Landrace and in Police Large White populations. The analyzed population was found to deviate from the Hardy-Weinberg equilibrium due to the higher value of heterozygous genotype, as also reported by Omelka et al. [19].

As far as it concerns the effect of RBP4 genotype on main reproductive traits of the studied population, it was revealed that both the $\mathrm{AA}$ and the $\mathrm{AB}$ genotypes were favored in producing statistically significant higher values of TNB, NBA, and NW traits (piglets/birth), rendering the A allele as an allele with an additive effect. Our results are in agreement 
with previous studies $[2,6,20]$, which reported that the AA genotypes were associated with higher TNB and NBA piglets/birth. Moreover, previous authors $[1,9]$ concluded that the presence of $B$ allele had a negative effect on the litter size, suggesting that A allele was in favor of prolificacy. In addition, Sun et al. [21] reported that crossbreed pigs with the AA genotype produced $0.72 \mathrm{TNB}, 0.64 \mathrm{NBA}$ more than the BB genotypic sows, while Gonçalves et al. [22] reported that A allele of RBP4 gene produced more piglets (TNB) and more live piglets per litter (NBA).

Contrary to our results, data obtained in other sows' populations (crossbreeds or pure breeds) failed to reach statistically significant difference in regard to the RBP4 genotypes and prolificacy $[16,23]$. Furthermore, other researchers noted that $\mathrm{BB}$ genotypes displayed higher litter sizes than the $A A$ and the $A B$ genotypes $[7,24]$. The $B$ allele originates from a Chinese pig [25] and is associated also with high fertility performance [26]. The fact that in the studied population the $B$ allele had a negative effect on the examined reproductive traits may reflect the absence of Chinese ancestors in our population.

It is worth noting that the AA genotype had also a negative impact $(p<0.05)$ on the number of piglets that were born dead, with respect to the other two genotypes $(\mathrm{AB}$ and $\mathrm{BB})$ reflecting indirectly a greater litter size. To our knowledge this is the first time that a certain genotype is associated with the number of piglets that may be born dead in a litter.

Recent developments in the porcine genome maps set the basis for the identification of individual genes that affect reproduction. Therefore, the application of MAS on swine production may become more efficient as more associations between markers and traits are identified. This seems to be promising especially for litter size due to the low heritability and the sex limited nature of these traits [27]. Allele effects may differ between lines or populations due to the genetic background, rendering the establishment of a certain genotype expressing an improved reproductive trait not an easy task [15]. The A allele of RBP4 seems to impart an additive effect on the litter size rendering itself as a potential molecular marker in pig breeding schemes.

\section{Conclusion}

Our results on the RBP4 gene polymorphism studied in a commercial pig population showed that polymorphism of the RBP4 gene can be related to litter size. Statistical analysis revealed that sows with AA genotype had statistically higher litter sizes than those with $\mathrm{BB}$ genotypes, which displayed lower TNB, NBA, and NW values and higher NBD value. In addition, according to our results, A allele of the RBP4 gene seems to render an additive effect to the desired phenotypic reproductive traits (litter size), suggesting that this allele can be included in future Marker-Assisted Selection programs in sows' populations.

\section{Conflict of Interests}

The authors declare that no potential conflict of interests was disclosed.

\section{Acknowledgments}

The authors would like to thank the owner and staff of the pig farm for their support to the data and samples collection. The authors would also like to acknowledge M.-A. Driancourt for his useful comments on the final paper. A. Marantidis was funded by the Greek State Scholarships Foundation, I.K.Y.

\section{References}

[1] M. F. Rothschild, L. Messer, A. Day et al., "Investigation of the retinol-binding protein 4 (RBP4) gene as a candidate gene for increased litter size in pigs," Mammalian Genome, vol. 11, no. 1, pp. 75-77, 2000.

[2] A. Spötter, S. Müller, H. Hamann, and O. Distl, "Effect of polymorphisms in the genes for LIF and RBP4 on Litter Size in Two German Pig Lines," Reproduction in Domestic Animals, vol. 44, no. 1, pp. 100-105, 2009.

[3] J. V. Yelich, D. Pomp, and R. D. Geisert, "Detection of transcripts for retinoic acid receptors, retinol-binding protein, and transforming growth factors during rapid trophoblastic elongation in the porcine conceptus," Biology of Reproduction, vol. 57, no. 2, pp. 286-294, 1997.

[4] J. P. Harney, T. L. Ott, R. D. Geisert, and F. W. Bazer, "Retinol-binding protein gene expression in cyclic and pregnant endometrium of pigs, sheep, and cattle," Biology of Reproduction, vol. 49, no. 5, pp. 1066-1073, 1993.

[5] W. E. Trout, J. J. McDonnell, K. K. Kramer, G. A. Baumbach, and R. M. Roberts, "The retinol-binding protein of the expanding pig blastocyst: molecular cloning and expression in trophectoderm and embryonic disc," Molecular Endocrinology, vol. 5, no. 10, pp. 1533-1540, 1991.

[6] L. Ollivier, L. A. Messer, M. F. Rothschild, and C. Legault, “The use of selection experiments for detecting quantitative trait loci with an application to the INRA hyperprolific pig," Genetical Research, vol. 69, no. 3, pp. 227-232, 1997.

[7] X. Wang, A. Wang, J. Fu, and H. Lin, "Effects of ESR1, FSHB and RBP4 genes on litter size in a large white and a landrace herd," Archiv für Tierzucht, vol. 49, no. 1, pp. 64-70, 2006.

[8] M. Muñoz, A. I. Fernández, C. Ovilo et al., "Non-additive effects of RBP4, ESR1 and IGF2 polymorphisms on litter size at different parities in a Chinese-European porcine line," Genetics Selection Evolution, vol. 42, article 23, 2010.

[9] A. Terman, M. Kmiec, D. Polasik, and K. Pradziadowicz, "Retinol binding protein 4 gene and reproductive traits in pigs," Archiv Tierzucht, Dummerstorf, vol. 50, pp. 181-185, 2007.

[10] A. Terman, M. Kmiec, D. Polasik, and A. Rybarczyk, "Association between RBP4 gene polymorphism and reproductive traits in polish sows," Journal of Animal and Veterinary Advances, vol. 10, no. 20, pp. 2639-2641, 2011.

[11] F. C. Yeh, R. C. Yang, and I. Boyle, POPGENE Version 1.32. Microsoft Windows-Based Freeware for Population Genetic Analysis, Center for International Forestry Research, University of Alberta, Edmonton, Canada, 1999.

[12] T. H. Short, M. F. Rothschild, O. I. Southwood et al., "Effect of the estrogen receptor locus on reproduction and production traits in four commercial pig lines," Journal of Animal Science, vol. 75, no. 12, pp. 3138-3142, 1997.

[13] J. P. Gibson, Z. H. Jiang, J. A. B. Robinson, A. L. Archibald, and C. S. Haley, "No detectable association of the ESR PvuII mutation with sow productivity in a Meishan x Large White F2 population," Animal Genetics, vol. 33, no. 6, pp. 448-450, 2002. 
[14] S. Dall'Olio, L. Fontanesi, L. Tognazzi, and V. Russo, "Genetic structure of candidate genes for litter size in Italian Large White pigs," Veterinary Research Communications, vol. 34, supplement 1, pp. 203-206, 2010.

[15] E. A. Kabalin, K. Starčević, S. Menčik, M. Maurić, V. Sušić, and I. Štoković, "Analysis of ESR and RBP polymorphisms in black Slavonian sows: prel results," Acta argiculturae Slovenica Supplement, vol. 4, pp. 45-48, 2013.

[16] G. Drogemuller, H. Hamann, and O. Distl, "Candidate gene markers for litter size in different German pig lines," Journal of Animal Science, vol. 79, no. 10, pp. 2565-2570, 2001.

[17] M. Kmieć, J. Dvořák, and I. Vrtková, "Study on a relation between estrogen receptor (ESR) gene polymorphism and some pig reproduction performance characters in Polish Landrace breed," Czech Journal of Animal Science, vol. 47, no. 5, pp. 189193, 2002.

[18] W. Kapelański, R. Eckert, H. Jankowiak, A. Mucha, M. Bocian, and S. Grajewska, "Polymorphism of ESR, FSHß, RBP4, PRL, OPN genes and their influence on morphometric traits of gilt reproductive tract before sexual maturity," Acta Veterinaria Brno, vol. 82, no. 4, pp. 369-374, 2013.

[19] R. Omelka, M. Martiniaková, D. Peškovičová, and M. Bauerová, "Associations between RBP4/MspI polymorphism and reproductive traits in pigs: an application of animal model," Journal of Agrobiology, vol. 25, pp. 77-80, 2008.

[20] L. A. Messer, L. Wang, J. Yelich, D. Pomp, R. D. Geisert, and M. F. Rothschild, "Linkage mapping of the retinol-binding protein 4 (RBP4) gene to porcine Chromosome 14," Mammalian Genome, vol. 7, article 396, 1996.

[21] Y.-X. Sun, Y.-Q. Zeng, H. Tang et al., "Relationship of genetic polymorphism of PRLR and RBP4 genes with litter size traits in pig," Zhongguo yi Chuan Xue Hui Bian Ji, vol. 31, no. 1, pp. 63-68, 2009.

[22] I. D. V. Gonçalves, P. B. D. Gonçalves, J. C. da Silva et al., "Interaction between estrogen receptor and retinol-binding protein-4 polymorphisms as a tool for the selection of prolific pigs," Genetics and Molecular Biology, vol. 31, no. 2, pp. 481-486, 2008.

[23] C. D. Blowe, K. E. Boyette, M. S. Ashwell, E. J. Eisen, O. W. Robison, and J. P. Cassady, "Characterization of a line of pigs previously selected for increased litter size for RBP4 and follistatin," Journal of Animal Breeding and Genetics, vol. 123, no. 6, pp. 389-395, 2006.

[24] A. Korwin-Kossakowska, W. Kapelański, M. Bocian, M. Kamyczek, and G. Sender, "Preliminary study of the RBP4, EGF and PTGS2 genes polymorphism in pigs and its association with reproduction traits of sows," Animal Science Papers and Reports, vol. 23, no. 2, pp. 95-105, 2005.

[25] B. J. Isler, K. M. Irvin, S. M. Neal, S. J. Moeller, and M. E. Davis, "Examination of relationship between estrogen receptor gene and reproductive traits in pig," Journal of Animal Science, vol. 80, no. 9, pp. 2334-2339, 2002.

[26] L. Alfonso, "Use of meta-analysis to combine candidate gene association studies: application to study the relationship between the ESR PvuII polymorphism and sow litter size," Genetics Selection Evolution, vol. 37, no. 4, pp. 417-435, 2005.

[27] M. F. Rothschild, "Genetics and reproduction in the pig," Animal Reproduction Science, vol. 42, no. 1-4, pp. 143-151, 1996. 

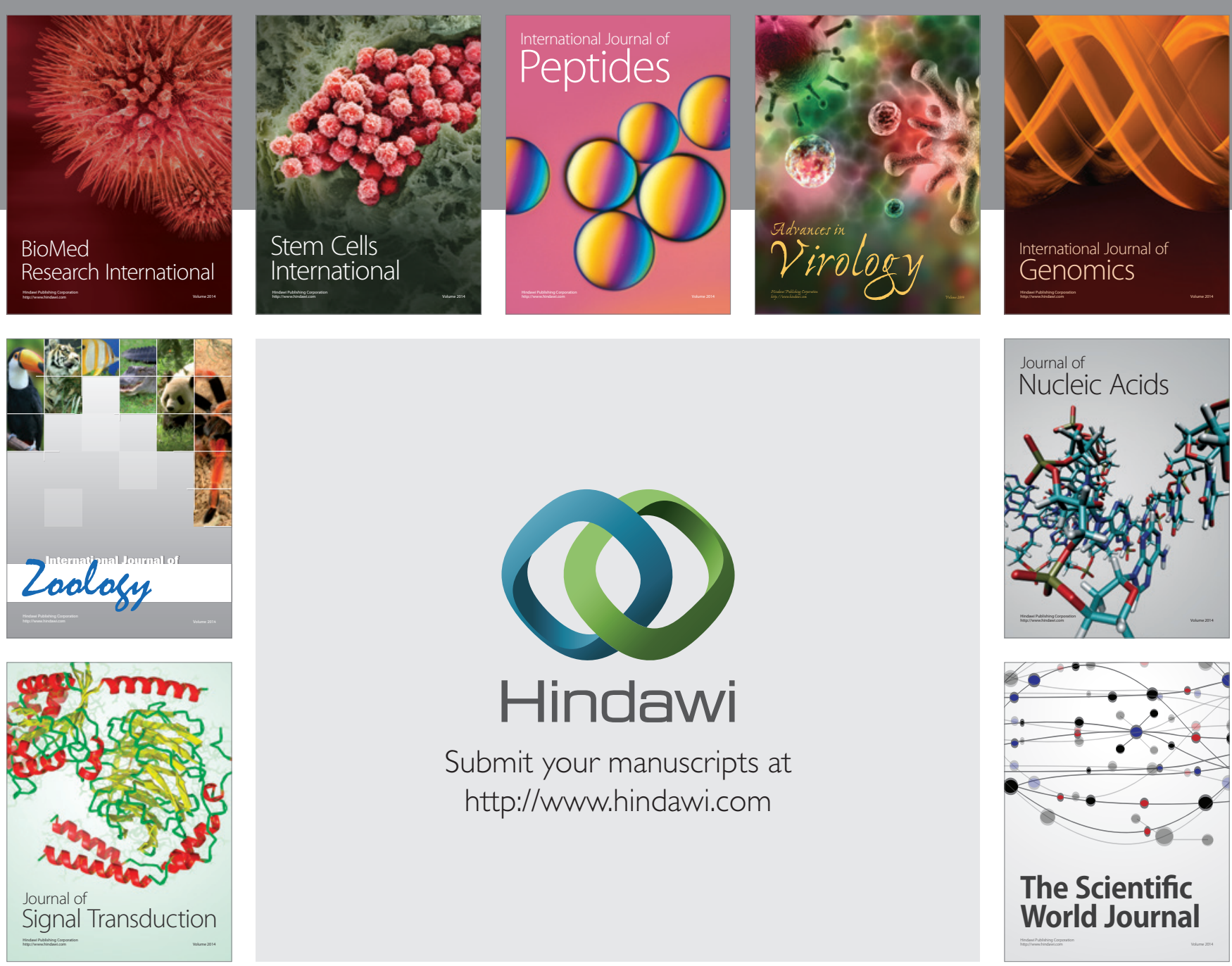

Submit your manuscripts at

http://www.hindawi.com
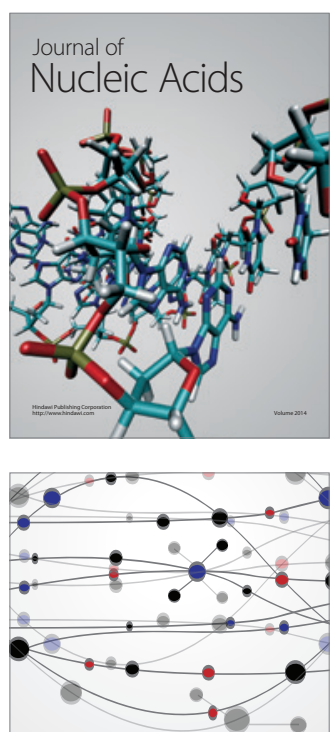

The Scientific World Journal
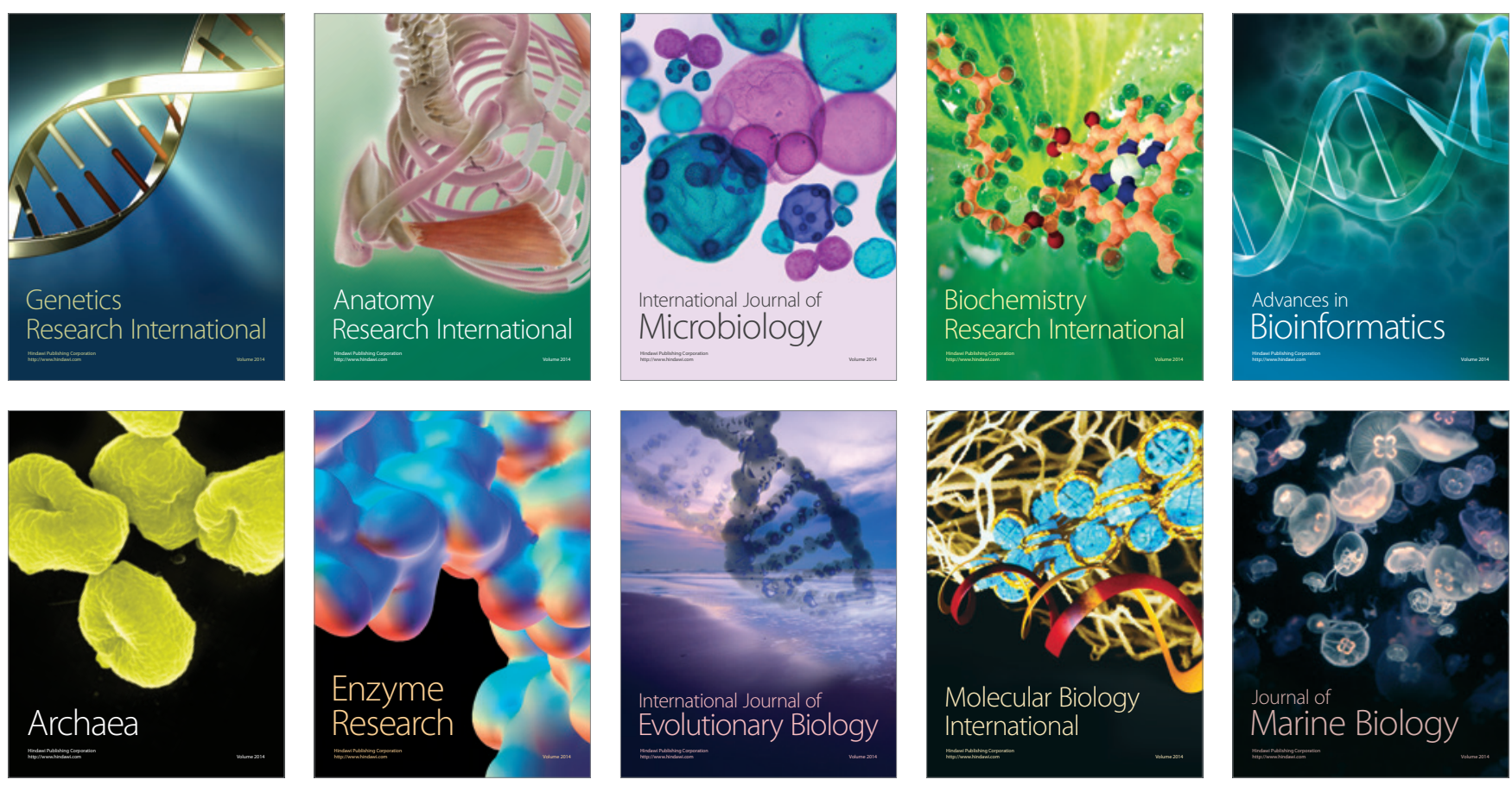